\title{
Not an invitation to rape: the Sexual Offences Act 2003, consent and the case of the "drunken" victim
}

\author{
GEORGINA FIRTH*
}

Law School, Lancaster University

\begin{abstract}
The aim of this paper is to look at the development of the law of consent in the light of 1 the changes in the law and consider whether the reforms have achieved their stated aims of providing "coherence and clarity". I will seek to argue that whilst there has been some progress and some recognition of the problems faced by rape complainants, changes to the substantive law alone will not make a significant difference, particularly in cases of rape involving alcohol. What is needed is a broader reform agenda which tackles problematic legal definitions but also seeks to change stereotypical perceptions of rape complainants through measures such as effective public information campaigns and the strategic use of expert evidence. In the light of these suggestions, it is argued that the decision of the government to abandon further reform proposals, such as a rebuttable presumption of non-consent where the victim is intoxicated, is a missed opportunity which has led to a return to the position prior to the Sexual Offences Act (SOA) 2003. The effect of this is that societal attitudes to rape and rape myths continue adversely to influence verdicts, to interfere with the proper consideration of the specific evidence in "difficult" cases, and to undermine the efforts of policy and legislation to bring about meaningful change.
\end{abstract}

\section{Introduction}

The law in relation to rape has received considerable attention in recent years. However, the focus of much of the reform has been on the substantive law and, in particular, the vexed issue of consent. The definition of consent set out in s. 74 of the SOA states that "a person consents if he agrees by choice and has the freedom and capacity to make that choice". The aim of enacting a statutory definition was to "bring coherence and clarity to the meaning of consent". ${ }^{1}$ To further this aim and reinforce the new definition, in March 2006 the government launched an advertising campaign. ${ }^{2}$ One of the advertisements contained a full-page image of a woman's torso. She is naked save for a pair of knickers with a no-entry sign emblazoned on the front. The text across the bottom of that page reads "Have sex with someone who hasn't said yes to it, and the next place you enter could be prison."3

\footnotetext{
The author would like to thank the anonymous reviewer for valuable comments on an earlier draft of this paper.

1 R v Bree [2007] EWCA Crim 256, at 22.

2 www.homeoffice.gov.uk/crime-victims/reducing-crime/sexual-offences/.

3 Arguably, the text of the advertisement is also objectionable as it presents a one-dimensional way of thinking about a woman's body as a place that another enters.
} 
Whilst the government's concern on this issue is laudable, it is somewhat disturbing that they considered that this was an appropriate image to convey the consent message. In choosing this image to get their message across, the government is, perhaps unwittingly, reinforcing the kind of stereotypes and rape myths that continue to plague the rape laws and ensure low conviction rates. The advertisement presents the woman as a body. The visual message seems to be that consent is to be read from that body and not from the context of what a woman says or her understanding of the situation (after all, she has no head with which to speak in the advert).

The problem raised by this advertising campaign - namely the ghostly silence of women's real voices and experiences from the rape trial - is one that has concerned feminists for many years ${ }^{4}$ and it is worrying that despite substantial reform the same issues continue to arise. Recent case law, such as Hagan, ${ }^{5}$ Dougal $^{6}$ and Bree, ${ }^{7}$ indicates clearly that the problems that feminist writers have long sought to identify in relation to consent and how it should be interpreted by the law have not been resolved. This is particularly the situation in the difficult cases, for example, those where there is a degree of acquaintance between the parties or where alcohol is involved. Undeniably, it is often difficult to determine how consent is given and understood under these conditions, but when important questions of definition remain in the hands of the judiciary will the position improve? The case of Bree would suggest not and it is a matter of concern that this case has led to the government abandoning proposals for further revision of the consent provisions under the Act, despite considerable academic and media criticisms of judicial and juror decision-making in this area. ${ }^{8}$

\section{The Home Office review and legislative change: the ghost of consent past}

As a starting point, it is worth considering the review that took place prior to the enactment of the SOA and setting out what it sought to achieve in terms of the protection of particularly vulnerable victims. Although the law on rape has undergone a number of legislative and procedural changes over a period of years, it is clear from the consistently poor conviction rates that there had been little improvement from the perspective of the female rape complainant. ${ }^{9}$ The most significant contribution to the process of reform in recent years is the SOA, which followed the Home Office consultation document Setting the Boundaries: Reforming the law on sex offences. ${ }^{10}$ The two-volume document was the result of a

4 For recent feminist engagements with this subject, see R Hunter and S Cowan (eds), Choice and Consent: Feminist engagements with law and subjectivity (Oxford: Routledge-Cavendish 2007), chs 3, 5, 6 and 9; J Temkin and B Krahe (2008) Sexual Assault and the Justice Gap: A question of attitude (Oxford: Hart (2008).

5 N Britten, "Student is cleared of raping fresher he was meant to be caring for", Daily Telegraph, 3 November 2006.

6 R v Dougal (2005) Swansea Crown Court (unreported). In this case, the prosecution offered no evidence on the basis that a drunken consent is still consent, after the complainant testified that she could not remember whether or not she had consented to intercourse. For criticism of Dougal, see: C Gammell, "Judge "dreadfully wrong' over rape ruling", The Independent, 24 November 2005; C Elliott and C de Than, "The case for a rational reconstruction of consent in criminal law" (2007) 70 Modern Law Review 225, p. 240, and the Court of Appeal in Bree [2007] EWCA Crim 256, para. 32.

7 [2007] EWCA Crim 256.

8 J Rozenberg, "Law on consent in rape cases is clear enough", Daily Telegraph, 21 June 2007. See also N S Rumney and R A Fenton, "Intoxicated consent in rape: Bree and juror decision-making" (2008) 71(2) Modern Law Review 271-302; J Temkin and A Ashworth, “The Sexual Offences Act 2003: (1) Rape, sexual assaults and the problems of consent" (2004) Crim LR 328-46; Elliott and de Than, "The case for a rational reconstruction", n. 6 above.

9 J Bindel, "Just another week of rapes", The Guardian, 29 May 2009; R Williams, "Postcode lottery in rape convictions getting worse", The Guardian, 10 June 2009.

10 Home Office, Setting the Boundaries: Reforming the law on sex offences (London: Home Office 2000). 
series of consultations, deliberations and proposals arising from the Review of Sex Offences, which was established by the Home Secretary to provide recommendations for "clear and coherent offences that protect individuals ... from abuse and exploitation, and enable abusers to be appropriately punished". ${ }^{11}$ Whether the specific recommendations in relation to the law of rape have achieved these objectives or, indeed, whether they even adequately address the problems raised are the focus of the next section.

Both Lacey ${ }^{12}$ and Rumney ${ }^{13}$ criticised the remit of the government review in so far as it focused exclusively on the revision of the substantive law of rape. The consequence of this focus was inevitably that important issues relating to the way in which legal definitions of rape are interpreted and enforced by the criminal justice system and the norms, assumptions, images and values that shape that enforcement process were excluded from consideration. As Rumney has argued, the exclusionary focus serves to "obscure the practices of criminal justice agencies that hinder the effective enforcement of the law" and gives the "implicit impression" that "such problems can be resolved by [a] limited revision of the substantive law". ${ }^{14}$

A further and connected danger of such an approach, identified by Lacey, was that, despite the review's apparent appreciation that sexual offences can be seen as tracing the boundaries of what is socially regarded as right and wrong in the area of sexual conduct, ${ }^{15}$ it downplayed:

one of the most powerful aspects of criminal law ... its reflection and reinforcement of certain ideas of the sexually normal, including the sex/gender roles and stereotypes which any informed reader of the research or observer of practice knows make a decisive difference to the implementation of sexual offences. ${ }^{16}$

It would therefore appear that the review's recommendations would do little to undermine the pervasive myths and stereotypes of female sexuality that have so long plagued the effectiveness of rape law from the point of view of complainants. This can be seen from both the judgment in Bree and the apparent lack of impact of the government's advertising campaign, referred to earlier, in changing public perceptions of "real rape". 17

Throughout its consideration of the law of rape, the review sought to strike a balance between what it saw as "the key moral imperatives of individual autonomy", 18 bearing in mind a perceived increased liberality in social attitudes towards sex, and the "protection of the vulnerable", recognising the harmful consequences of sexual assault. Amongst the conclusions drawn as a result of this balancing exercise was a proposal to widen the scope of the definition of sexual intercourse and an attempt to uncover and then specifically define the boundaries of the constructs of consent and non-consent. ${ }^{19}$

11 Home Office, Setting the Boundaries, n. 10 above, Jack Straw at vol. 1, p. i.

12 N Lacey, "Beset by boundaries: the Home Office Review of Sex Offences", (2001) 3 Crim LR, p. 11.

13 P Rumney, “The review of sex offences and rape law reform: another false dawn?" (2001) 64 Modern Law Review 890, p. 890.

14 Ibid. p. 890.

15 Vol. 1, para. 1.1.3.

16 Lacey, "Beset by boundaries", n. 12 above.

17 This has since been confirmed by research into the impact of the advertising campaign. See Temkin and Krahe, Sexual Assault, n. 4 above.

18 Lacey, "Beset by boundaries", n. 12 above, p. 5 .

19 I use the term construct here in the context of legal reform. However, I appreciate that consent is something much more than just a legal or social construct. 


\section{Consent and communicative sexuality: consent futures?}

Feminist critique has long argued that the lack of a statutory definition of consent in rape has allowed gender myths and stereotypes to expand the space for male subjectivity and allowed the defendant to read off consent from the complainant's demeanour, body and sexual reputation at the expense of her voice. The review recognised and re-affirmed the centrality of consent/non-consent to the offence of rape ${ }^{20}$ but appreciated that it was not unproblematic. It saw the problems inherent in the concept of consent as being due to the lack of a clear statutory definition. It therefore proposed to overcome these difficulties by defining consent as "free agreement" 21 and by setting out a non-exhaustive list of examples, illustrating circumstances in which consent in the sense of free agreement is not present. It was suggested that this list could form the basis of model judges' directions; for example:

In deciding whether the complainant did freely agree to sexual intercourse ... you should not assume that the complainant did freely agree just because they did not say or do anything ... [or] just because they did not protest or physically resist. ${ }^{22}$

The review made clear that, in defining consent, it was not seeking to change its meaning ${ }^{23}$ but to enable judges to explain clearly what the law says and juries to understand "just what is meant by consent". 24 The definition of consent approved by the review is now found in s. 74 of the SOA, which states: "A person consents if he agrees by choice and has the freedom and capacity to make that choice." This definition is supplemented by s. 75 , which contains six evidential presumptions against consent, and s. 76, which contains two conclusive presumptions of non-consent. ${ }^{25}$ Interestingly, the review's recommendation that there be an evidential presumption against consent where a person was too affected by alcohol to give free agreement ${ }^{26}$ did not find its way into the law because of concerns by the Home Secretary that such a presumption would lead to "mischievous accusations". ${ }^{27}$

20 Home Office, Setting the Boundaries, n. 10 above, vol. 1, paras 2.10.1-3. Interestingly, the review claimed that it was not changing the meaning of consent but merely providing clarification. I would argue that this claim is somewhat disingenuous and that by inscribing a communicative model of sexuality into the meaning of consent, the review is indeed attempting to change the way in which consent is understood. From a feminist perspective, this is to be welcomed. However, whether this change in meaning will have a practical effect on the conduct of the rape trial in the absence of a corresponding change in the contextual, evidential and social norms is to be doubted. See also Rumney's consideration of how this shift may alter perceptions of criminal liability: Rumney, "The review", n. 13 above, p. 903.

21 Clarified by the review as a voluntary agreement between two parties to engage in sexual intercourse: Home Office, Setting the Boundaries, n. 10 above, vol. 1, paras 2.10.4-5.

22 Ibid. vol. 1, paras 2.11.1-6. At para. 2.10.6, the review expressed the opinion that the provision of guidelines on the meaning of consent would help both practitioners and jurors in coming to decisions in particular cases. Unfortunately, the government rejected this standard direction and the formulation of a standard direction was left to the Judicial Studies Board and the Court of Appeal.

23 Ibid. vol. 1, para. 2.10.3. See n. 33 below and the accompanying text.

24 Ibid.

25 For a critique of the provisions and, in particular, the way in which consent was framed and the working of the presumptions, see Temkin and Ashworth, "The Sexual Offences Act”, n. 8 above. McEwan argues that it is not clear that those presumptions will have much effect on the process or outcome of a case in J McEwan, "Proving consent in sexual cases: legislative change and cultural evolution" (2005) 9(1) International Journal of Evidence and Proof 1.

26 Home Office, Setting the Boundaries, n. 10 above, vol. 1, para. 2.10.9.

27 Home Office, Convicting Rapists and Protecting Victims: Justice for victims of rape (London: Home Office 2006), ch. 3 . 


\section{Communicative sexuality - a desirable but problematic notion}

As Rumney notes, the use of free agreement as the basis of a definition of consent indicates the increasing influence of the concept of "communicative sexuality" within rape law. ${ }^{28}$ Communicative sexuality gained purchase in feminist legal thought through an article in 1989 by Lois Pineau entitled "Date rape: a feminist analysis". Pineau was writing at the height of the concern in 1980s USA about the phenomenon of acquaintance or date rape. ${ }^{29}$ Her aim was to argue for the more effective criminalisation of non-consensual sex amongst acquaintances in which there was no physical injury or threat of injury by developing a model of communicative sexuality. She critiqued the existing law on the basis that the current legal definition of consent focused on what the man thought was happening. In Pineau's view, in deciding whether or not a rape occurred, the focus should be directed towards whether or not the woman actually consented to the sexual encounter. ${ }^{30}$ She posited that the court should therefore work backwards from actual consent to an understanding of when it is reasonable for a man to believe that there was consent. ${ }^{31}$

Pineau moved on from this proposition to develop criteria for consensual sex. She started from the assumption that it is not reasonable for women to agree to coerced sex or for men to believe that women have so agreed. ${ }^{32}$ Her strategy for arguing this was, firstly, to seek to dispel the myths that posit a normal seduction as aggression and submission ${ }^{33}$ and then, in its place, to develop a picture of a sexual relationship that undermined the current gendered view that pressured sex can also be consensual. For Pineau, the essence of a good sexual relationship is mutuality, "communicative sexual partners will not overwhelm each other with the barrage of their own desires . . . a person engaged in communicative sexuality will be most concerned with the mutuality of desire". 34

She asserts that in sexual relationships, as in friendships, each person has a duty to respect the other and in order to develop this mutual respect and understanding there is a need for communication. ${ }^{35}$ Aggressive or coercive sex lacks this "essence of mutuality" and, therefore, Pineau suggests that it is not sex to which it would be reasonable for a woman to consent or for a man to believe that she is consenting and thus to pursue. ${ }^{36}$ Pineau asserts that non-consent in legal terms would therefore be made out when it can be shown that the sex involved in the allegation was not "communicative". 37 As Rumney notes,

28 Rumney, "The review", n. 13 above, p. 899.

29 L Pineau, "Date rape: a feminist analysis" (1989) 8 Law \& Philosophy 217, p. 236. For a review of the background to the article and a consideration of Pineau's argumentation, see the introduction in L Francis, Date Rape: Feminism, philosophy and the law (University Park PA: Pennsylvania University Press 1996). Pineau's article is also reprinted in full in this book. Pineau's model of communicative sexuality has been the subject of a lively debate, particularly among male commentators. For examples of a variety of criticisms of Pineau's model, see chs 2-4 in Francis. For a male perspective, see M Cowling, Date Rape and Consent (Aldershot: Ashgate 1998).

30 Pineau, "Date Rape", n. 29 above, p. 224.

31 Ibid. pp. 234-5.

32 Ibid.

33 Ibid. pp. 225-33.

34 Ibid. p. 236.

35 Ibid. p. 235.

36 Ibid. p. 234.

37 Ibid. pp. 239-40. Critics of Pineau have sought to argue that this model of sexuality fails to encompass women who enjoy submissive sex. However, I would argue that there is nothing in Pineau's model that prevents these women communicating this desire to their partners in advance. For an example of Pineau's model in action, see the Antioch College Sexual Offence Policy discussed in Francis, Date Rape, n. 29 above, pp. xviii, 65-7, 135-75. 
at face value, the notion of free agreement may have benefits for rape complainants seeking to prove their cases in that it challenges the assumption that a woman is available for intercourse when she is in no position to choose and the belief that coercion may be an acceptable means by which to force a woman into sex. ${ }^{38}$ This could also have repercussions for cases where women are so heavily intoxicated that it is arguable that their ability to make choices is significantly impaired. However, that will depend upon a robust interpretation of capacity to consent as I will discuss later.

Feminist legal thought has long argued that free agreement involving notions such as respect for the autonomy of others and sexual integrity should lie at the heart of any legal definition of rape and its enforcement. ${ }^{39}$ Free agreement clearly has the potential to be more effective in constructing sexual encounters where there is no agreement, verbal or otherwise, as rape. ${ }^{40}$ This may explain Rumney's observation that the review's recommendations concerning free agreement appear to have received little critical comment. ${ }^{41}$ Many other jurisdictions had already adopted the notion of communicative sexuality in their definitions of consent ${ }^{42}$ and the review had access to information about the content and structure of this legislation in a number of jurisdictions. ${ }^{43}$ However, the available research on the operation of the model in other jurisdictions would seem to suggest that the inscription of communicative sexuality into the core concepts of rape law is not unproblematic, both ideologically and procedurally. ${ }^{44}$

In her original article and in a response to her critics, ${ }^{45}$ Pineau suggested that her model of communicative sexuality would open the way for rape prosecutors to shift the focus of blame from the complainant to the defendant through questioning that focused on what actions the accused took to ensure that she was consenting. ${ }^{46}$ The government review seemed to have taken Pineau's argument on board when it stated that such a shift would take place as a result of their definition of consent. ${ }^{47}$ However, I would argue that the current reality of rape trials in England is such that the claim that the focus of rape trials will shift because of this new definition alone is problematic. The government initially appeared to recognise this in the recent consultation paper Convicting Rapists and Protecting Victims - Justice for victims of rape. ${ }^{48}$ However, the fact that it has now abandoned further proposals for reform of the substantive law following Bree may be a missed opportunity.

38 Rumney, "The review", n. 13 above, p. 899.

39 N Lacey, Unspeakable Subjects: Feminist essays in legal and social theory (Oxford: Hart 1998); N Naffine, "Possession: erotic love in the law of rape" (1994) Modern Law Review 10.

40 Some commentators have argued that free agreement implies something more than silence and that it may be problematic where a woman remains silent, not through fear but through a willingness to engage in sex. However, Rumney suggests, and I would concur, that consensual yet silent sex is unlikely to give rise to an allegation of rape. Rumney, "The review", n. 13 above, p. 903.

41 Ibid. p. 899. Rumney here is referring specifically to Lacey, "Beset by boundaries", n. 12 above; M Bowley, "New Labour, new sex", NLJ, 28 July 2000, p. 1134; J Temkin, "Getting it right, sexual offences law reform", NLJ, 4 August 2000, p. 1169.

42 Rumney, "The review", n. 13 above, pp. 899-901.

43 Home Office, Setting the Boundaries, n. 10 above, vol. 2, Appendices E, F and G.

44 For a critique of the Australian and New South Wales models, Naffine, "Possession", n. 39 above, pp. 23-9. In relation to the US model, see P R Sanday, A Woman Scorned: Acquaintance rape on trial (London: University of California Press 1996), ch. 12.

45 L Pineau, "A response to my critics", in Francis, Date Rape, n. 29 above, ch. 5.

46 Pineau, "Date rape", n. 29 above, pp. 240-1.

47 Home Office, Setting the Boundaries, n. 10 above, vol. 1, para. 2.11.4.

48 Home Office, Convicting Rapists, n. 27 above. 
To assume that a cultural and procedural change in the trial process would occur overnight through the enactment of a statutory definition alone would be somewhat naive. Rumney suggests, and this has to some extent been borne out, that the communicative model may be helpful in cases where the complainant suffers serious physical harm, where there is corroborative evidence, or where the woman is incapable of communicating agreement because she is unconscious through, for example, drugs or drink. ${ }^{49}$ However, as he notes, the court very often interprets these scenarios as "real rapes" in any event and, thus, convictions are less difficult to obtain. ${ }^{50}$

In the area of acquaintance rape, where the law has great difficulty in distinguishing between consensual sex and rape, it is difficult to envisage how this new definition would shift the focus decisively away from the complainant without further elaboration. She still has to give evidence and be cross-examined. Her behaviour, dress and demeanour are still subject to detailed examination and comment by the defence counsel "in order to establish whether or not there was agreement, the nature and content of that agreement and whether there was any ambiguity in what the complainant said or did". ${ }^{51}$ Further, even though the SOA departed from the subjective Morgan defence of honest belief ${ }^{52}$ and replaced it with a test of reasonable belief, this belief has been interpreted as partly subjective and therefore the defendant's point of view as to whether or not there was free agreement remains the legal point of view and, thus, possibly decisive when this defence is run. ${ }^{53}$ This was confirmed by the Court of Appeal in the recent decision of Bree. ${ }^{54}$

Ideologically, the notion of free agreement clearly raises the issue of the "respective responsibilities of men and women". 55 Several commentators have suggested that the standard will not only require men to ensure that they have consent but also place a burden on women to communicate clearly. This is recognised by the review. ${ }^{56}$ However, this implicit requirement may be potentially problematic as it may underline beliefs that women are in some way responsible for rape when they have not clearly and perhaps verbally and physically, through resistance, expressed their non-consent. As Rumney notes, "given the prevalence of attitudes within both society and the criminal justice system which attribute

49 Rumney, "The review", n. 13 above, p. 900.

50 Ibid. p. 900.

51 Ibid. p. 901. Carol Smart, in Feminism and the Power of Law (London: Routledge 1989), pp. 34 and 42, notes that telling the story of rape inevitably reveals ambiguities, for example, a woman may agree to intimacy but not intercourse. In a trial when credibility is in issue, these ambiguities will be used to discredit her account of rape and subsume the rape into the "normal" pattern of submission and the individual woman into a single category of "Woman" known to be "capricious and mendacious".

52 Lacey notes that the review justified its stance by asserting the disproportionate costs to the defendant and victim of establishing consent on the one hand and of a mistake being made on the other: Lacey, "Beset by boundaries", n. 12 above, p. 12.

53 Whilst the review suggested that the controversial Morgan defence should remain, it did recommend that the defence should not be available if the accused did not take all reasonable steps in the circumstances to ascertain free agreement at the time; or where the defendant was in a state of self-induced intoxication, or if the defendant was reckless: Home Office, Setting the Boundaries, n. 10 above, vol. 1 para. 2.13.8. Contrary to the review's recommendations, the Act replaced the Morgan test with a test of reasonable belief. However, the courts have applied the test of reasonableness in a similar way to the reasonableness requirements of the defence of provocation. This means that characteristics of the defendant will be taken into account. See Temkin and Ashworth, "The Sexual Offences Act", n. 8 above.

54 R v Bree [2007] 2 All ER 676, para. 34. On this point see, J Elvin, "Intoxication, capacity to consent and the Sexual Offences Act 2003” (2007) King's Law Journal 151, p. 156.

55 Rumney, “The review”, n. 13 above, p. 901, and Pineau, "Date rape”, n. 29 above, pp. 234-5.

56 Home Office, Setting the Boundaries, n. 10 above, vol. 1, para. 2.10.3. 
blame for sexual violence to women ${ }^{57}$ (it is not unreasonable to assume that) any notion of responsibility may disproportionately fall on the woman". ${ }^{58}$ I will return to this issue of responsibility later in relation to cases of rape involving alcohol.

A further potential difficulty, inherent in the notion of free agreement, is that it appears to place considerable emphasis on the nature and quality of communication. Research evidence from Canada and the United States ${ }^{59}$ has clearly indicated that current gendered notions of the normality of a coercive model of sexual intercourse mean that men (and women) have internalised gendered myths about women's willingness to engage in sexual intercourse. For example, that a woman who initiates a date, enters a man's flat or accepts dinner from him is expressing a willingness to sleep with him or even that such actions entitle a man to sleep with a woman against her wishes. ${ }^{60}$ The review potentially added to these problems by recognising both verbal and non-verbal sexual consent. ${ }^{61}$ This wide notion of communicative sexuality is arguably positive in that it recognises the reality of sexual relations. ${ }^{62}$ However, it also potentially allows defendants to contradict complainants' verbal expressions of non-consent by feeding into the myths and stereotypes already referred to. Such myths and stereotypes continue to play an important if hidden role in the trial process and, thus, the notion of free agreement alone is unlikely to unequivocally benefit complainants or substantially increase the protection offered by the criminal law. ${ }^{63}$

Despite the inferences that can be drawn following the changes in the law in the Criminal Justice and Public Order Act 1994, s. 34, there is still no requirement that the defendant give evidence in English law, even though the new definition requires in s. 1(2) that the jury consider the defendant's reasonable belief in "all of the circumstances including any steps the defendant has taken to ascertain whether the victim consents". 64 Furthermore, there is no guarantee that a complainant's account will withstand cross-

57 See M Amir, Patterns in Forcible Rape (London: University of Chicago Press 1971) in relation to notions of complainants' contributory negligence.

58 Rumney, "The review”, n. 13 above, p. 901.

59 For example, see: T P Humphreys and E Herold, "Date rape: a comparative analysis and integration of theory" (summer 1996) 5(2) Canadian Journal of Human Sexuality 69; D M Truman, D M Tokar and A R Fischer, "Dimensions of masculinity: relations to date rape supportive attitudes and sexual aggression in dating situations" (July-August 1996) 74 Journal of Counselling \& Development 555; V Van Wie, A M Gross and B P Marx, "Females' perception of date rape: an examination of two contextual variables" (December 1995) 1(4) Violence Against Women 351.

60 Ibid.

61 Home Office, Setting the Boundaries, n. 10 above, vol. 1, para. 2.10.4. Some authors have argued that nothing less than a specific "yes" should count as consent. See S Schulhofer, Unwanted Sex: The culture of intimidation and the failure of law (London: Harvard University Press 1998). However, other commentators have argued that communicative sexuality as a concept is objectionable because it appears to focus less on the presence of consent than on how someone should consent to sex: see H Reece, "When a woman says 'no' she means 'no", NLJ, 7 November 1997, p. 1616. I would, however, agree with Rumney and the Campaign against Rape, when they argue that Reece has misunderstood communicative sexuality. There is nothing in Pineau's work to suggest that she wishes to stipulate where people should have sex or what sexual positions they should adopt. For Pineau, these are matters of individual choice based upon mutual communication and respect.

62 For a full discussion, see D Archard, Sexual Consent (Boulder: Westview Press 1998).

$63 \mathrm{~J}$ Kelly, J Lovett and L Regan, A Gap or a Chasm? Attrition in reported rape cases, Home Office Research Study 293 (London: Home Office 2005); E Finch and V E Munro, "Juror stereotypes and blame attribution in rape cases involving intoxication: the findings of a pilot study" (2004) 44 BJ Crim 1-14; E Finch and V E Munro, "The Sexual Offences Act 2003: intoxicated consent and drug assisted rape revisited" (2004) Crim LR 789; E Finch and V E Munro, "Breaking boundaries? Sexual consent in the jury room" (2006) 26(3) Legal Studies 303-20.

64 Criminal Justice and Public Order Act 1994, s. 34; Sexual Offences Act 2003, s. 1(2). 
examination ${ }^{65}$ or that there will be sufficient corroborative evidence to persuade a jury to convict. ${ }^{66}$ Therefore, the evidential and procedural standards that continue to govern the trial process will ensure that the primary focus of rape trials will continue to be on the complainant and the defendant's perception of her state of mind. Given the current high attrition rates and the attitudes of the police and Crown Prosecution Service to rape allegations, any refocusing of the trial process is unlikely to benefit many complainants without a concomitant refocusing of societal and institutional attitudes to acquaintance rape, as will become clear when the case of Bree is considered below. ${ }^{67}$

\section{The case of the intoxicated victim: consent unravelled again or the spectre of the past?}

Recent cases ${ }^{68}$ decided using the new definition of consent appear to demonstrate that the concerns raised at the time of the reform have now been realised and that, in isolation, the new definition of consent has not had a significant effect on conviction rates in rape cases. ${ }^{69}$ Arguably, many of the cases that have been reported in the media involve particularly difficult issues, combining the question of acquaintance (however brief) and the role of alcohol in sexual encounters. However, it is precisely these difficult cases which have contributed to the high attrition rates in rape cases and prompted the need for reform in this area, so it would seem that they are an important indicator of the success or otherwise of the new definition. ${ }^{70}$ Several of these cases (Dougal in particular) raised renewed concern about the effectiveness of the definition of consent in the SOA and in particular, whether it can offer protection to women in especially vulnerable situations. These concerns were reinforced by research that indicates that juries are reluctant to convict men of rape in cases in which the victim has been drinking. ${ }^{71}$

As a result of the publicity surrounding cases such as Dougal, the Home Office revisited the issue of consent in the consultation paper, Convicting Rapists and Protecting Victims: Justice for

65 Although there does appear to be evidence that false allegations of rape are rare. See S Lees, Carnal Knowledge: Rape on trial (London: Penguin 1996).

66 Rumney, “The review”, n. 13 above, p. 900. Z Adler, Rape on Trial (London: Routledge \& Kegan Paul 1987); Lees, Carnal Knowledge, n. 65 above; and J Temkin, "Prosecuting and defending rape: perspectives from the Bar" (2000) 27 Journal of Law and Society 219 have all recorded the marked reluctance of juries to convict defendants in cases involving a degree of acquaintance. This, of course, corresponds with the widespread societal views shown in psychological studies that such assaults are less serious than assaults by strangers and, indeed, in some circumstances, that they are not rape at all.

67 Rumney, "The review", n. 13 above, fully addresses the limitations of the review in relation to the procedural and evidential difficulties that were not addressed, for example, victim unwillingness to seek legal redress, attitudes and practices of criminal justice personnel and jurors' attitudes (pp. 904-9). These issues have already been addressed to some extent elsewhere and therefore it did not seem appropriate or necessary to re-address them here. Rumney concludes, and I would agree, "effective legal change will only occur when there is an inclusive process of law reform that examines formal legal rules, their interpretation and enforcement" (p. 910). See also Lacey, "Beset by boundaries", n. 12 above, pp. 11-13.

68 R v Dougal (2005) Swansea Crown Court (unreported); R v Hagan (2006) Nottingham Crown Court (unreported). For media reports of these cases see: G Roberts, "Drunken consent to sex is still consent, judge rules", The Independent, 24 November 2005; N Britten, "Student is cleared", n. 5 above.

69 R Williams, "Postcode lottery", n. 9 above.

70 In relation to attrition rates generally, see L Kelly, Rape in the 21st Century: Old behaviours, new contexts and emerging patterns, Full Research Report, ESRC End of Award Report, RES-000-22-1679 (Swindon: ESRC 2007).

71 Finch and Munro, "Breaking boundaries?”, n. 63 above, p. 306; Finch and Munro, "The Sexual Offences Act 2003", n. 63 above. The research indicated that juries believed that it was reasonable for a man to assume that a woman's silence amounted to consent, even when it was due to intoxication. They tended to hold a drunken victim partially responsible for what happened and they were less inclined to see taking advantage of a drunken woman as rape. 
victims of rape. ${ }^{72}$ One of the key proposals in the paper was to consider whether consent needs further clarification in relation to the question of capacity, either in the form of a further definition and/or the creation of an evidential presumption. ${ }^{73}$ However, the judiciary expressed considerable hostility to the proposals on consent in the consultation paper and the Court of Appeal took the opportunity in the case of $B r e e^{74}$ to undermine the consultation process and reclaim questions of interpretation as matters best left to the courts. ${ }^{75}$

Benjamin Bree had been convicted of the rape of a 19-year-old student. In brief, the facts of the case were that he had spent an evening drinking with the student, who shared a flat with his brother. On their return to the flat, the complainant was sick and Bree helped her to wash her hair. Her next memory was of finding herself on the bed with Bree having sex with her. She told the jury that she had not consented. Bree's defence was that the sex was consensual and that he reasonably believed that she was consenting. The Court of Appeal held that the essential question in this case was not whether the parties to the case were less inhibited because they had been drinking, no whether they might have regretted what had happened, nor whether they had acted irresponsibly, but simply whether the evidence proved that the appellant had intercourse with the complainant without her consent. ${ }^{76}$ The judgment states that neither party had acted unlawfully in drinking to excess and that both were free, if they wished, to have intercourse with each other. The court qualified the position somewhat saying that if, through drink or any other reason, the complainant has temporarily lost her capacity to choose whether to have intercourse on the particular occasion, she is not consenting and, subject to questions about the defendant's state of mind, if intercourse took place, this would be rape. However, where the complainant has voluntarily consumed even substantial quantities of alcohol but nevertheless remains capable of choosing whether or not to have intercourse and in drink agrees to do so, this would not be rape ${ }^{77}$ Finally, the court concluded that there was a clear definition of consent and that to try to set a level of intoxication that would negate consent would not be possible. Otherwise, "provisions intended to protect women from sexual assaults might very well be conflated into a system, which would provide patronising interference with the rights of autonomous adults to make personal decisions for themselves". ${ }^{78}$

The judgment appears, on the face of it, to be attempting to protect individualistic notions of personal and sexual autonomy. However, I would argue that the Court of Appeal in Bree dismissed the numerous concerns ${ }^{79}$ that had been raised about the new definition too easily, situating the difficulty as one raised by the "infinite circumstances of human

72 Home Office, Convicting Rapists, n. 27 above.

73 Home Office, Convicting Rapists, n. 27 above, ch. 3. As noted above, this was not a new concern and the review prior to the SOA 2003 had recommended that a person was unable to consent when too affected by alcohol to give free agreement (para. 2.10.9). This suggestion was not included as a presumption under s. 75 due to a concern expressed by the Home Secretary about false accusations.

74 R v Bree [2007] 2 All ER 676.

75 J Rozenberg, "Judges reject government rape reforms", The Telegraph, 24 January 2007; C Dyer, "Judges try to block rape trial reforms", The Guardian, 23 January 2007.

76 R v Bree [2007] 2 All ER 676, para. 26.

77 Ibid. para. 34. The guidelines set out in Bree can now be found in the specimen direction in cases involving intoxication in the March 2010 version of the Crown Court Bench Book at www.jsbni.com/ Publications/BenchBookRevisedApr2010.doc.

78 Ibid.

79 For example, Temkin and Ashworth, "The Sexual Offences Act", n. 8 above; Elliott and de Than, "The case for a rational reconstruction", n. 6 above; Finch and Munro, "The Sexual Offences Act 2003”, n. 63 above. 
behaviour" 80 rather than lack of clear statutory guidance. ${ }^{81}$ The judgment can be seen as problematic in two ways. Firstly, whilst there are some attempts to focus on the legal issues at stake, ${ }^{82}$ it fails to take proper account of the fact that the legal rules are not always applied and interpreted by juries free of entrenched attitudes and behaviours which may be damaging to rape complainants in cases involving alcohol. Secondly, the court failed to take the opportunity to clarify the issue of the definition of capacity and to map this on to a legal definition of consent in a meaningful way.

\section{Capacity and consent: when should drunken consent equate to legal consent?}

The main issue at appeal was the lack of guidance on the issue of consent from the trial judge to the jury and the judgment of the Court of Appeal agreed that the jury should be given assistance on the question of capacity and the extent it can take this into account when determining the issue of consent. However, it is noteworthy that nowhere in the judgment did the court set out to clearly define capacity or to provide a model direction on consent for trial judges to follow so it remains unclear what guidance on these issues jurors should be given in future cases. The specimen direction on capacity in the 2010 edition of the Crown Court Bench Book follows Bree on this, in that it simply states that "where a question of capacity arises in the evidence it must be left for the jury to decide". ${ }^{83}$ In the course of the judgment, the Court of Appeal approved the pre-2003 case law and I suggest it is likely that in seeking to guide juries in the future, trial judges will resort to this case law and the pre-2003 definitions of consent that have been problematic for complainants as too much discretion is left to jurors and their interpretation of what "satisfies the ordinary meaning of consent". 84

The judgment in Bree starts by setting out the relevant provisions of the 2003 Act and deals with some of the debate prior to the Act. In this way, the Court of Appeal is indicating that it is aware of the debates and is sensitive to the issues that led to reform. However, the judgment immediately seeks to legitimate and reclaim the interpretative role of the judiciary in relation to the legislation by situating the difficulty in these cases as one of proof and not ideology and, in doing so, it sidesteps the need to further define the capacity element of the new definition. It notes that the Act is intentionally silent on the question of consent and the voluntary consumption of alcohol and suggests that this is because the law was already clear. ${ }^{85}$ Sir Igor Judge states that the presumptions negating consent set up in ss. 75 and 76 of the Act deal with matters of "common sense". It is held to be obvious that there would be no consent where the victim is insensible and equally, it is a matter of common sense that voluntary intoxication was not covered by the legislation, as it is a complex matter of proof to be decided by reference to the facts on a case-by-case basis. In this way, the judgment is using common sense and questions of proof as rhetorical devices to reclaim the judicial high ground, avoid the need for further legislative intervention (such as a presumption of non-consent when the victim is heavily intoxicated, or a more generous

80 R v Bree [2007] 2 All ER 676, para. 36.

81 Rumney and Fenton, "Intoxicated consent", n. 8 above.

82 R v Bree [2007] 2All ER 676, paras 25-6.

83 Crown Court Bench Book, n. 77 above, p. 371. See also Hysa [2007] EWCA Crim 2056.

84 Elliott and de Than, "The case for a rational reconstruction", n. 6 above, p. 234. See also Rumney and Fenton, "Intoxicated consent", n. 8 above; Elvin, "Intoxication", n. 54 above, pp. 151-7.

85 Para. 27 of the judgment is important in this respect. The Court of Appeal states that before the 2003 Act, it was not difficult to identify the relevant legal principle and for the judge to explain the law. It approves judicial directions in Malone [1998] 2 CAR 447 and Lang [1976] 62 CAR 50 and disapproves at the same time any question of further legal definition imposed by government. The clear implication is that there is no need for any further definition as the judiciary filled the gap in the law 30 years ago. 
interpretation of capacity) and state that the judges are best placed to determine where the line between consent and non-consent should be drawn.

In relation to intoxicated complainants who are less than insensible, the judgment explicitly rejects the Home Office's argument that consent or capacity has a special meaning that should be determined by legislation and argues that such cases are best decided by relying on the ordinary meaning of the term consent. Sir Igor Judge notes that questions about consent when affected by voluntary intoxication can cover a wide range of states of mind and as such are social matters rather than something that lends itself to legislation. ${ }^{86}$ It can be seen that, without explicitly stating that it is doing so, by linking the term consent with a state of mind that should be determined on the facts of the individual case, the Court of Appeal is seeking to import into s. 74 the definition of consent found in Olugboja. ${ }^{87}$ The consequence of this is that, as in Olugboja, the judiciary is placing itself in a position of authority. There are clear indications throughout the judgment in Bree that determining the correct level at which intoxicated consent is no longer "real" consent is not something that the jury can do unaided, after all, that is what happened in the Crown Court in this case and led to the appeal. ${ }^{88}$ It is a matter for the judge and the jury is to accept the judge's analysis of consent up to that point. The Court of Appeal appears to be arguing that setting the appropriate level of voluntary intoxication that negates consent would be too complex a matter for legislation because of the infinite variety in the facts of a particular case. For the Court of Appeal, the ordinary meaning of consent is a matter of common sense, is sufficiently clear, should depend on the individual facts of the case and is a matter for the jury to fix by applying its good sense and knowledge of human behaviour to the facts of the case.

The question that therefore arises is: what is the ordinary meaning of consent that the judiciary is applying here? Is it the complainant's state of mind that is in issue or could it be the defendant's state of mind, taking into account what he reasonably believed? How are the jury to determine when the line between real but intoxicated consent and rape is crossed? The Court of Appeal refused to fix a formula. It argued that it is a matter for the jury taking into account standards with which the jury is said to be familiar. ${ }^{89}$ However, to prevent the jury fixing the boundary in the wrong place, it is stated that the role of the judge is to steer the jury to the right point through the discourses in the summing up. ${ }^{90}$ In reclaiming this role for itself, the judiciary is inferring that its understanding of common sense is drawn from and encompasses societal and cultural notions of what is right and appropriate. Common sense is a rhetorical device used to indicate the difference between real rape where the victim is unconscious (and there is little difficulty in proving the fact of rape) and the situation where the victim has voluntarily become intoxicated, consent is in issue and proof is more sensitive and difficult. In reclaiming an interpretative role, the judge is placed in a position of authority as the most likely person to be able to find the truth of an allegation. However, as Wallerstein notes, "in the case of the capability of the drunken

86 In making this argument, the Court of Appeal rather disingenuously relies on the article by Temkin and Ashworth, which notes the philosophical difficulty in defining concepts such as freedom, choice and capacity and points out that the definitions remain "at large": Temkin and Ashworth, "The Sexual Offences Act", n. 8 above, p. 336.

87 Gardner's analysis of Olugboja clearly makes this link between consent and state of mind: S Gardner, “Appreciating Olugboja" (1996) 16(3) Legal Studies 275.

88 R v Bree [2007] 2 All ER 676, paras 39-42.

89 Ibid. paras 35 and 36.

90 Ibid. para. 39. 
woman to consent to sex, the plummeting rate of rape convictions proves that common sense seems to fail". 91

In seeking to address the criticism that arose following the case of Dougal, and in order to justify its position, the court built on the analogy between drunken consent and drunken intent that had been raised in the earlier case and which led to the phrase "a drunken consent is still consent". However, as Wallerstein argues, such an analogy, which equates intoxicated intent with consent in the criminal law, is at the very least controversial and potentially misleading. ${ }^{92}$ She suggests that this is because the rationale underlying the law on intoxication applies to acts done by an offender that lead to harm to another. The issue at stake, however, in cases such as Bree are the actions of voluntarily intoxicated victims.

To equate the victim's consent to the offender's intent is to extend the rationale of the law relating to the offender's intoxication onto the drunken victim [and] to imply that there can be no recognition of the victim's drunkenness as negating her consent because there is some fault in voluntarily getting drunk. ${ }^{93}$

Arguably, a woman might put herself in a vulnerable position if she chooses to get drunk but this does not mean that she is making an indirect choice to have sex. In making this link between the terms intoxicated intent and consent, there are suggestions in the judgment that when a woman chooses to get drunk, she is implicitly choosing to have sex. This reflects a worrying set of assumptions and values as I shall discuss further below. ${ }^{94}$

In contrast to the opinion expressed by the Court of Appeal and some commentators, ${ }^{95}$ I would suggest that one of the key rationales behind the judgment, the statement that "drunken consent is still consent", is too simplistic and is problematic for several reasons. Whilst Bree established that intoxication does not necessarily deprive a person of the capacity to consent, it does not attempt to give guidance on the point at which capacity to consent is lost. ${ }^{96}$ As was made clear by Sir Igor Judge, the presumptions in ss. 75 and 76 will not apply in these difficult cases and so the s. 74 definition is central. I would not dispute that identifying the point at which a complainant becomes incapable of consent does depend in part on the facts and the available evidence. ${ }^{97}$ However, I would suggest the definition in s. 74 requires more than this. Even when a person appears to have agreed as a matter of fact on the available evidence, what needs to be considered is whether they are capable of agreeing and this necessitates a legal interpretation of the key issue of capacity in the case of a conscious but very drunk victim. This is because the definition of consent set out in s. 74 is clearly intended to require more than factual agreement as it includes the terms "capacity" and "freedom to consent". It is only when all three conditions are met that consent in law is present. As Wallerstein argues:

The question of whether a person is capable of agreeing must therefore be understood as a legal question about the conditions of mental capacity under which the law would recognise factual consent as a basis of legal consent. ${ }^{98}$

91 S Wallerstein, "A drunken consent is still consent - or is it? A critical analysis of the law on a drunken consent to sex following Bree" (2009) 73 JCL 318-44, p. 343.

92 S Wallerstein, "A drunken consent", n. 91 above, p. 323.

93 Ibid. p. 326.

94 For a fuller consideration of the arguments against conflating intent and consent in this way see ibid.

95 See, for example, J Elvin, “The concept of consent under the Sexual Offences Act 2003" (2008) 72 JCL 519.

96 R v Bree [2007] 2 All ER 676, para. 39.

97 Rumney and Fenton, "Intoxicated consent", n. 8 above, p. 283.

98 Wallerstein, "Drunken consent”, n. 91 above, p. 321. 
In Bree, whilst the court recognised in principle the "vanishing capacity to consent", 99 it did not go on to develop this point or apply it to the facts of the case. ${ }^{100}$ Instead, the focus of the judgment in relation to the voluntarily intoxicated victim in this case was interpreted restrictively to be a question of a lack of "actual" consent rather than lack of capacity to consent. ${ }^{101}$ In this way, the court was able to focus on issues of proof and avoid the question of the need for further definition. Given that the victim in this case was, as the judgment recognised, extremely drunk, it would therefore seem post-Bree, that the law requires proof of a very high degree of intoxication, almost to the point of unconsciousness, before capacity to consent is negated. Does this really reflect the fair balance between recognising sexual autonomy and protecting the vulnerable that the review was attempting to achieve with the new definition, or should a much lower level of intoxication be required to negate capacity to consent? Alternatively, given the difficulties in establishing the point at which capacity is lost, should there be a default position set out in a presumption that drunken consent is not consent? ${ }^{102}$ This might be one way of tackling the hidden assumptions that influence so many judgments in cases of rape involving alcohol and which informed the decision in Bree as I will now move on to discuss.

\section{Rape myths and alcohol}

In taking pains to be seen not to patronise women, it could be argued that the court placed too much emphasis on what might be termed "positive autonomy" at the expense of recognising "negative autonomy", 103 or the right to say no and have your no taken seriously. This latter emphasis may have been a consequence of the judicial hostility to further legislative intervention but as, Finch and Munro's studies have shown, ${ }^{104}$ lack of clear legal principles and guidance on them can lead to juries relying on rape myths to inform their understanding and, thus, further undermine women's claims of non-consent in particular cases.

The issue of sexual autonomy is a complex one and there are undoubtedly tensions between the recognition of positive autonomy and the protection of negative autonomy. However, it could be argued that the court's focus on positive autonomy sends out the wrong message and fails to recognise the vulnerability of victims whose choices may be impaired by their alcohol intake. ${ }^{105}$ The argument that setting high standards for what qualifies as consent would deprive women of their autonomy is only valid if we ignore the powerful role of the law in setting standards and assume that sexual autonomy in all of its

99 Wallerstein, "Drunken consent", n. 91 above, p. 321.

100 However, see the later case of $\mathrm{R} v \mathrm{H}$ [2007] EWCA Crim 2056 where the court did state that capacity to consent is a legal question independent of the question of unconsciousness.

101 It was noted that during the trial, the prosecution had, in the light of the complainant's evidence, changed its position from suggesting that the complainant was so drunk that she was unconscious to the position that she was conscious, had only a patchy memory of events, but nevertheless did not consent. The Court of Appeal in Bree suggested that this change was a move away from claims of lack of capacity to a claim of lack of actual consent. This analysis is questionable.

102 Wallerstein argues for a default position that drunken consent is not consent. However, she seems to propose that this should form part of the legal definition of capacity in $\mathrm{s} .74$ rather than a separate presumption of non-consent: Wallerstein, "Drunken consent", n. 91 above.

103 Elliott and de Than, "The case for a rational reconstruction", n. 6 above, p. 231. For a further discussion of this issue see A Wertheimer, Consent to Sexual Relations (Cambridge: CUP 2003); and Elvin, "Intoxication", n. 54 above, pp. 151-7.

104 Finch and Munro, "Juror stereotypes", "The Sexual Offences Act”, and "Breaking boundaries”, n. 63 above. See also Rumney and Fenton, "Intoxicated consent", n. 8 above, p. 289.

105 Throughout the judgment, stress is laid on the complainant's voluntary consumption of alcohol. For example, see paras 25, 26, 39. This was contrasted with the presumptions which deal with complainants who are involuntarily at an advantage (para. 24). 
aspects is a right that can be straightforwardly exercised. However, given the connections drawn between women's drinking and rape in the media, ${ }^{106}$ the political discourses and even in the government's own campaigns, ${ }^{107}$ it would seem that women's "right" to drink and to consent to sex or not when they have been drinking is far from straightforward.

It is clear from the judgment that the court implicitly accepts that alcohol is a normal element of socio-sexual relations and it is at pains to make clear that it is not suggesting that a person cannot consent to sex when they have been drinking. ${ }^{108}$ However, in accepting the normalisation of the connection between alcohol and sexual relations, the court fails to address the damage done by the myths about rape involving alcohol which have arguably been at the root of the problem with conviction rates. A growing body of research has recognised that rape convictions are particularly low in cases where alcohol is involved due to the fact that juries are influenced by cultural discourses which can lead to stereotypical views of appropriate gender behaviour. ${ }^{109}$ Examples of this are the myths that women lack the ability to directly communicate sexual desire and that they become more sexually promiscuous when drunk. Numerous studies have shown that women who become part of a drinking culture, or who flirt when drunk, are considered "loose" by a proportion of the population. ${ }^{110}$ From this, as Meyer has shown in relation to an analysis of a number of media articles, it is a small step to equate consenting to get drunk in the company of men to consenting to sex and to holding women accountable for rapes involving alcohol.111 Thus, rape involving alcohol becomes re-presented as a problem of female drinking rather than male violence. As Meyer has argued, female drinking then becomes integrated into the blame culture because it is argued that it impairs the woman's ability to provide for her own safety, makes her vulnerable and, thus, constitutes irresponsible and unwise behaviour. ${ }^{112}$ The language of the judgment in confirming and supporting the phrase "drunken consent is still consent" seems almost to be legitimising the practice of drunken sex and setting it up as a question of mutual responsibility. ${ }^{113}$ This notion of mutual responsibility is to some extent, as discussed earlier, consistent with the notions of free agreement which are behind the definition in s. 74. However, in taking this view, the Court of Appeal (and the review that drafted the new definition) fails to clearly address the fact that the risks of heavy drinking mostly accrue to women, as juries may interpret the behaviour of women who drink heavily in the company of men as "asking for it". Stating that both parties were autonomous adults ${ }^{114}$ fails to recognise this fact and risks undermining aspects of the very autonomy that the court claims it is at pains to protect.

Further, contrary to research showing that rape in an acquaintance situation is more harmful in some ways than stranger rapes, because of the breach of trust involved, ${ }^{115}$ such myths reinforce the idea that rape involving alcohol is not serious because the victim's

106 A Meyer, "Too drunk to say no" (2010) 10(1) Feminist Media Studies 19-34.

107 See A Wollenberg, "Blaming the victim", The Guardian, 8 July 2008, on the advice given out in an advert from Directgov on drinking and rape, which seems to imply that if you are drunk and a victim of rape then you are to blame.

108 R v Bree [2007] 2 All ER 676, para. 25.

109 For example, see Kelly et al., A Gap, n. 63 above; Finch and Munro, "Juror stereotypes”, "The Sexual Offences Act" and "Breaking boundaries?", n. 63 above.

110 Kelly et al., A Gap, n. 63 above; Finch and Munro, "Juror stereotypes", "The Sexual Offences Act" and "Breaking boundaries?", n. 63 above.

111 Meyer, "Too drunk", n. 106 above, at p. 26.

112 Ibid. p. 29.

113 R v Bree [2007] 2 All ER 676, paras 25 and 26.

114 Ibid.

115 Home Office, Setting the Boundaries, n. 10 above. 
drinking was voluntary. ${ }^{116}$ This voluntariness is something that is stressed by the Court of Appeal throughout the judgment and it makes a clear distinction between the complainant's voluntary intoxication in this case and the presumptions which the court states are designed to deal with victims who are involuntarily at a disadvantage.

The judgment fails to appreciate, when allocating responsibility for risky behaviour, that men do not bear an equivalent risk and they are not expected to modify their behaviour. ${ }^{117}$ This position therefore questions women's victim status, as they have failed to protect themselves. It also fails to recognise that it is not simply the consumption of alcohol that produces vulnerability, but also the setting in which it occurs, namely men's reactions to women drinking. ${ }^{118}$ In this way, the court implies that rape involving alcohol becomes a problem of female heavy drinking and not male rape. Women are seen as accountable not only for their own behaviour in making themselves vulnerable but also for not being able to stop any potential rapist. ${ }^{119}$ Such reasoning ignores the fact that when women (victims) are at risk, the man (offender) is the risk. It might be argued that shared responsibility in these situations is only fair, but I would suggest that in placing the behaviour of the victim and offender on an apparently equal footing, the court is drawing a "flawed comparison of vastly different situations as if they had the same meaning and consequences". 120 This problem is compounded in the courtroom situation as the right to get drunk and consent to sex turns into the victim's responsibility to prove her non-consent and justify her actions because the burden of proof rests on her and an assessment of her evidence. ${ }^{121}$ This was seen in Dougal, where evidence of impaired memory due to heavy intoxication on the part of the victim, rather than being seen as evidence to support her lack of capacity, was fatal to the prosecution. ${ }^{122}$

\section{Reconsidering reform - or drinking is not a crime: rape is}

Bearing in mind the problems with the judgment in Bree set out above, it is suggested that the addition to the legislation of a rebuttable presumption that drunken consent is not consent in cases of heavy voluntary intoxication should be reconsidered. As was argued above, the end result of voluntary intoxication may put a complainant in a disadvantageous situation similar to those already covered by the existing presumptions under s. 75 . Perhaps more importantly, the reasons given for omitting to include such a presumption - in particular the risk of false allegations being made, are not supported by the available research evidence. ${ }^{123}$ Neither are concerns that to include an evidential presumption in relation to voluntary intoxication would impact negatively on the defendant's right to a fair trial. ${ }^{124}$ If a defendant genuinely misjudges a woman's level of intoxication then, subject to s. 1 of the Act and the reasonability of his belief, he will not be convicted of rape, regardless of the existence of the presumption. If, on the other hand, he is unsure of her level of intoxication and suspects that it has affected her capacity to consent, then a presumption

116 Meyer, "Too drunk", n. 106 above, p. 24.

117 Ibid. p. 27.

118 Ibid. p. 27.

119 Ibid. p. 29.

120 Ibid. p. 30

121 Ibid. p. 30.

122 Bree appeared willing to accept that this might not be the case but did not take the further step of suggesting that such evidence might instead be corroborative of the victim's lack of capacity to consent.

123 Home Office, Convicting Rapists, n. 27 above, at p. 15 and Hansard (HC) 19 November 2002, col. 512.

124 The application and use of the existing evidential presumptions seems to indicate that they are fairly easily rebutted. Of course, this might be an argument against including such a presumption. However, as I argue above, the benefits of such a presumption go beyond the scope of the individual trial. 
would be important in reminding the jury that the question to be considered is not only whether the complainant consented but whether the defendant was aware that she had drunk to the level where she had lost her capacity to consent. ${ }^{125}$ Finally, as Rumney notes and as argued above, the omission of such a presumption appears to make a distinction between the "deserving" and "undeserving victim"126 and, thus, feeds into precisely the kind of sexual stereotypes that the reforms to the law were supposed to challenge. As the consultation process showed, the wording of such a presumption would be difficult for the reasons given by the Court of Appeal. ${ }^{127}$ However, in the light of the recurrent difficulty with low conviction rates, would it not be better for legislation to err on the side of caution by including the voluntarily intoxicated and thus send out a clear message to society? ${ }^{128}$ Given the powerful role of the criminal law in reinforcing appropriate sexual behaviour, this could be an effective educational tool, if combined with an equally effective advertising campaign, which directly sought to tackle victim-blaming attitudes. ${ }^{129}$

The Court of Appeal accepted that leaving consent and capacity to the jury may permit different decisions in similar cases. This is confirmed by Finch and Munro's research, which shows that, in the absence of further definition, mock jurors interpret capacity in different ways leading to different outcomes in similar situations. ${ }^{130}$ However, the court justifies this by suggesting that it can be tempered by judicial direction and is in the interests of protecting sexual autonomy and allowing individuals to set their own limits. ${ }^{131}$ Of course, whether this is a good thing depends on whose autonomy is being protected and what type of autonomy. The available research on the effects of alcohol on sexual behaviour and rape $^{132}$ indicates that a significant number of rape victims were intoxicated at the time of intercourse leading to the conclusion that the use of alcohol is pervasive as a tool in acquaintance rape. ${ }^{133}$ Further research indicates that there is a commonplace practice of "loosening women up" with alcohol as a precursor to making sexual advances 134 and that

125 See also Wallerstein, "Drunken consent", n. 91 above, p. 341.

126 Rumney and Fenton, "Intoxicated consent", n. 8 above, p. 288. The deserving victim would not allow herself to get drunk and if she does get drunk then she does not deserve the protection of the law.

127 R v Bree [2007] 2 All ER 676 at para 35

128 Rumney and Fenton, "Intoxicated consent", n. 8 above, p. 289.

129 Temkin and Krahe, Sexual Assault, n. 4 above, pp. 109-23, suggested that the current Home Office campaign had not been effective. However, a more recent campaign by Rape Crisis, Scotland has been evaluated much more positively. The "This is not an Invitation to Rape Me" campaign attempts to confront victim-blaming attitudes in a direct way using a range of images and supporting materials which invite the viewer to examine their attitudes to a range of situations surrounding relationships, drink, dress and levels of intimacy. The stated aim of the campaign is to support women who have been raped, assign responsibility to the (male) attacker and to challenge victim-blaming attitudes. This campaign originally ran in the USA using posters, stickers and public service announcements to attack the perception that when a woman is raped, she asked for, deserved or wanted it. The campaign has also been supplemented in Scotland by a TV advert entitled "Not Ever".

130 Finch and Munro, "Breaking boundaries?" n. 63 above, p. 306; Finch and Munro, "The Sexual Offences Act", n. 63 above.

131 R v Bree [2007] 2 All ER 676, para. 38. The court refers to the "myriad of circumstances in which the issue of consent may arise". On this point see Gardner, "Appreciating Olugboja", n. 87 above, p. 281.

132 HMCPSI, Report on the Joint Inspectorate into the Investigation and Prosecution of Cases involving Allegations of Rape (London: HMSO 2002); P Sturman, Report on Drug Assisted Sexual Assault (London: Home Office 2000).

133 Finch and Munro, "Intoxicated consent", n. 63 above, at p. 779; N T Harrington and H Leitenburg, "Relationship between alcohol consumption and victim behaviours immediately preceding sexual aggression by an acquaintance" (1994) 9 Violence and Victims 315-24.

134 D L Masher and D L Anderson, "Macho personality, sexual aggression and reactions to guided imagery of realistic rape" (1986) 20 Journal of Research and Personality 77-89; P Y Martin and R A Hummer, "Fraternities and rape on campus" in P B Bart and E G Moran (eds), Violence Against Women: The bloody footprints (California: Sage 1983); HMCPSI, Report, n. 132 above; Sturman, Report, n. 132 above. 
sexual seduction is often linked with drink spiking. ${ }^{135}$ Given that the new statutory definition was said to be informed by an understanding that persons engaging in sexual activity have to understand the consequences of their acts and research has shown that such foresight of consequences is unlikely in later stages of intoxication, is this really a matter that could not be successfully dealt with by further legislation possibly coupled with the use of expert evidence regarding the effects of alcohol on a drunken woman's mental capacity to consent? ${ }^{136}$ After all, one of the aims of the legislation was to inform the public about the boundaries of acceptable sexual behaviour. This could be supplemented by an effective advertising campaign such as the current Rape Crisis Scotland campaign and the use of expert evidence in relation to alcohol consumption and capacity to further educate juries. As Conaghan and others have noted, the law already recognises some situations when a person's ability to make important choices is significantly impaired and it has been prepared to set limits on what is acceptable in relation to the defence of intoxication for specific intent crimes, so why is this not possible in relation to intoxication and consent? ${ }^{137}$

Further, are the legal principles set out in the Act really so unproblematic, or could they be expressed in such a way as to alleviate some of the problems raised in this type of case? Contrary to the views of the Court of Appeal, academic commentary continues to criticise the legislative provisions as "extremely vague". ${ }^{138}$ Following the Court of Appeal decision in Bree, the concepts of freedom, choice and capacity continue to be left open to jury discretion and possible prejudice. In the interests of clarity, would it not have been better for the court to endorse a statutory definition of capacity that could build on some of the more positive aspects of the previous case law? ${ }^{139}$ Elvin suggests that a possible definition could state that the complainant does not have the capacity to consent where her knowledge and understanding are so limited that she is not in a position to decide whether to agree. ${ }^{140}$ However, I would prefer a slightly wider definition which could more clearly encompass those who had been drinking heavily, such as the victims in Bree, Dougal and Hagan, namely victims who were so drunk that they were vomiting, and possibly unable to walk unaided and talk coherently. Admittedly, it is quite difficult to frame such a definition clearly, which means, as Wallerstein notes, that there would still be a wide grey area, but ideally such a definition should take into account that heavy drinking can distort a person's decisionmaking to the extent that it negates her ability to give meaningful consent. ${ }^{141}$ This would make clear to the jury that knowledge and understanding are integral to consent and would take into account the negative as well as the positive aspects of sexual autonomy.

I would argue that returning to the Olugboja interpretations of consent allows the law of rape to continue to reflect male perceptions. The judgment in Bree clearly reflects the fact that, despite reform, the law has not overcome its difficulties in distinguishing between rape and consensual sex. By detaching consent from its broader context ${ }^{142}$ and leaving important issues of definition to the judge and jury, the precise myths and stereotypes that

135 CentreLGS, Response to the Office for Criminal Justice Reform's Consultation Paper: Convicting rapists and protecting victims of rape-justice for victims of rape (AHRC Research Centre for Law, Gender and Sexuality, July 2006), www.kent.ac.uk/clgs.

136 HMCPSI, Report, n. 132 above; Sturman, Report, n. 132 above.

137 CentreLGS, Response, n. 135 above.

138 Elliott and de Than, "The case for a rational reconstruction”, n. 6 above, p. 238; Temkin and Ashworth, "The Sexual Offences Act”, n. 8 above.

139 Scarman LJ in Lang (1976) 62 Cr App R 50 stated that "the critical question is . . whether the [complainant] understood her situation and was capable of making up her mind".

140 Elvin, "Intoxication”, n. 54 above, p. 155.

141 Wallerstein, "Drunken consent”, n. 91 above, p. 332.

142 For fuller arguments on the contextualisation of consent, see Lacey, Unspeakable Subjects, n. 39 above. 
the Act sought to avoid risk being reintroduced. Further, by situating consent as a matter of proof on the facts of the individual case, the court continues to fail to appreciate the context in which rape takes place. Rather than encouraging a communicative model of consent and shifting the doctrinal boundaries of rape in the direction that the review intended, this return to previous principles could have the effect of undermining the experiences of women who allege rape under such conditions as being "real" rape and fails to take the step of appreciating that sex under such conditions is very different from consensual sex.

The underlying rationale of the judgment would appear to be a reclaiming of judicial discretion in the way in which consent is put before a jury. This allows the judiciary to maintain a strict control of the facts and themes in summing up a case. What this means in practice is that a judge in an individual case can manipulate the discourses of consent to privilege a particular notion of heterosexuality and to reward women who exhibit approved characteristics. In this way, through its strict control of the discourses, the law will be able to continue to police the sexuality of women and maintain the privileged position of malecentred notions of sexual intercourse at the heart of rape law. It could be argued that, despite the research which shows jurors tend to import myths and stereotypes into the jury room and their decisions, ${ }^{143}$ in the Bree case, they got it right and that their instincts are being undermined by the judiciary. Experience has shown that judges are not adept at providing scope within the discourses of rape trials for a mutuality of sexual desire or women's affective experiences. Through a subtle process of gender construction, the judgment defines and limits female experience to a social and cultural stereotype: namely that women are inclined to lie about allegations of rape and men need protection from women's dangerous sexuality. Bree undermines the harm done to rape complainants by unwanted intercourse, subordinates the language of the Act to the common sense of the judiciary, and reinscribes into the law the very myths and stereotypes about heterosexual relations that the legislation was designed to undermine.

\section{Laying the ghosts to rest?}

My consideration of the reform of the law on consent would seem to indicate that, whilst the changes in isolation may be a step in the right direction, they have had little effect on their own. This has led to some commentators suggesting that improvement could only be achieved if rape law moves away from a focus on consent. ${ }^{144}$ This is a matter that merits further research and consideration. However, I would tentatively suggest that such a move would not necessarily lead to a less one-dimensional understanding of sexual autonomy or recognise the reality that consent cannot be removed from the circumstances in which choice is made. Instead, I would suggest that what is required is, firstly, a more generous definition of consent which allows a much lower level of intoxication to negate the capacity to consent and, secondly, public information campaigns aimed at displacing the gender roles, myths and stereotypes which interfere with the appraisal of specific evidence in cases and undermine the efforts of policy and legislation. To some extent this is already happening and should be encouraged. ${ }^{145}$ However, it is a shame that the government

143 Finch and Munro, "Juror stereotypes", n. 63 above; G Chambers and A Millar, Prosecuting Sexual Assault (London: Scottish Office/HMSO 1986); Lees, Carnal Knowledge, n. 65 above; Kelly et al., A Gap, n. 63 above.

144 V Tadros, "Rape without consent” (2006) 26 Oxford J Legal Stud 515; M Madden Dempsey and J Herring, "Why sexual penetration requires justification" (2007) 27 Oxford J Legal Stud 467.

145 Home Office, Convicting Rapists, n. 27 above. 
allowed the media and the courts to undermine its recent consultation on rape. ${ }^{146}$ The consultation paper, like the National Consent Campaign, was not unproblematic for feminist analyses in that it continued to place the emphasis in rape law on the regulation of male sexuality rather than the protection of women's sexual autonomy. However, as Conaghan and others argued in their response, the symbolic power that an evidential presumption could have wielded should not have been underestimated. ${ }^{147}$ One of the stated aims of the SOA was to protect the victim's autonomy. A presumption dealing with self-induced intoxication would have been an important educative tool to indicate to juries (and the public at large) that it is the victim's state and not the means by which it is achieved that is important in determining the point at which consent is negated. This social and cultural role of the law is important as it is not the law in abstract but the law in its social, cultural and philosophical context that has been so effective in undermining rape complainants' experiences. However, as $\mathrm{R} v$ Bree demonstrated, the most well-meaning law reform is always subject to consideration and interpretation by a judiciary still not well versed in issues of gender awareness. ${ }^{148}$ Unless and until law reform is considered in such an inclusive manner, effective legal change remains a distant dream.

146 For an example of some of the media comment on the issue, see I Oakeshott, "Men who rape drunk women face tougher law", Sunday Times, 17 June 2007; J Clarke, "Men warned to check for consent before sex", The Independent, 7 March 2006

147 CentreLGS, Response, n. 135 above.

148 For recent research on judicial attitudes to law reform in this area, see Temkin and Krahe, Sexual Assault, n. 4 above, chs 6-7. 